feet. We got as far as the monastery of Kikko that day, and the next day I continued along the watershed to the camp at Troodos. Our road as far as Kikko was a mere track on the side of the hill, in some parts rather dangerous, and we had to lead our ponies or foot, in many parts very steep. The difficulty on the road is the want of water at that elevation. We halted the first night at a beautiful spring, but we had to carry with us food for man and beast for the whole party, muleteers, \&c. The scenery was wild and romantic. This spot is the centre of the 'moufflon' ground; three of them were at the spring when we approached it. It gave me a clearer idea of the forests of Cyprus than I ever had before.

"We have bad a great deal of rain this winter, and the country is clothed with vegetation."

\section{MINERAL RESOURCES OF THE UNITED STATES ${ }^{1}$}

THIS volume, published by the United States Geological Survey, is the first statistical report upon the condition of the mining industries of the United States, and contains much valuable information concerning the great and ever-increasing production of metals, especially in the States west of the Missouri and the Rocky Mountains.

In addition to the columns of figures of weights and values constituting the statistical matter proper, the author, or rather his coadjutors, for the volume is the work of many contributors, have furnished notices and descriptions of processes, especially in the metallurgical section; and a review of the course of the markets for the preceding eight years (to 1875) is given for each important metal. By a curious provision in the Act of Congress providing for the publication of these statistics, the field is restricted to mineral products other than gold and silver, but, in order to present as complete a view of the total output as possible, the best available figures of the production of precious metals are given in a concise form. This, though valuable, is rather disappointing, as we miss the interesting accessory descriptions which are given in other parts of the volume. How important the production of these metals has been during the last quarter of a century is seen in the statement that the aggregate yield up to the middle of last year has been 2707 tons of gold and I 5,680 tons of silver, and of these enormous quantities less than I per cent. of the gold, and none of the silver was raised before 1858 At the present time the annual production varies from i2 to 16 millions sterling coinage value, divided about equally between gold and silver, the latter being usually a little in excess.

The coal raised in the different States is a little over 87 million tons, of which 29, I20,000 tons were anthracite and the remainder bituminous coal and lignite of all kinds, and $s$ me anthracite mined "outside" of Pennsylvania, the recorded value being $29,326,000$ l. The above totals represent I. 8 ton per head per annum of the population, which is, however, somewhat less than the consumption, in addition to enormous quantities of wood and charcoal. Among the most interesting recent developments are the Tertiary and Cretaceous coal-basins which extend along tive base of the Rocky Mountains and are also seen at different points on the Pacific Coast, the total area of these being reported as greater than those of the Carboniferous formations proper in the Eastern States. These areas are, however, marked as doubtful by the author. At Crested Butte and Irwin, in the very heart of the Rocky Mountains, both antbracite and good coking coals are found in these newer formations, the quality of the latter especially being comparable with the coal of Connellsville or the best coking coal in Pennsylvania.

I "Mineral Resources of the United States." By Albert Williams, jun. 8vo. (Washington, $188_{3}$.)
The iron industry of the United States is now of first-rate importance, and the subject is well treated in a paper contributed by Mr. J. M. Swank, the well-known secretary of the American Iron and Steel Association. The iron ore raised is in round numbers 9 million tons, and the pig iron made from it $4,623,000$ tons. The value of the latter is given at $21,267,000 \mathrm{l}$., which is only a few pounds less than that of the gold, silver, copper, and lead taken together. The largest production of iron ore is in the district producing the richest quality, namely Lake Superior, whose yield of $2,948,000$ tons is comparable with those of the other great hematite districts of the world, Furness, Whitehaven, and Bilbao.

The United States are now among the largest producers of copper, and here we are met by the peculiarity of the unequal distribution of the producing centres. Thus, of a total product of 40,903 tons, 25,439 tons were from a single district, namely, Lake Superior, and of this again the larger proportion, I4,309 tons, was from a single mine, the "phenomenal" Hecla and Calumet of Houghton, Michigan. The Lake copper is entirely produced from the native metal, and is of the highest degree of purity. Latterly, however, a competitor of some importance has arisen in the south, in the barren desert country of Arizona, where masses of carbonates and oxides have been discovered in considerable quantity under conditions resembling some of the famous mines of South Australia. The handling of these ores is not, however, easy. The smelting must be done on the spot, and when the furnaces are at a distance from railways, the coke used may cost from 10l. to $15 l$. per ton. The most remarkable mine in this district, the Copper Queen, has already paid 200,000l. in profits, and produces copper at a cost of $4 \frac{1}{2} d$. to $5 d$. per pound.

Lead is another metal in which the United States have taken a prominent position during the last few years, the product being now 132,890 tons, while in 1870 it was only i 7,830 tons. This great increase is due to the development of several important groups of mines in the Western States, but more particularly in Utah, Nevada, and Colorado, the latter State alone producing 58,642 tons, or nearly half the total production of the country; while in I 873 the State was credited with only 56 tons. This enormous increase is due to the development of the carbonate deposits of Leadville, in the Rocky Mountains, where ores containing only to to 20 per cent. of lead are smelted in enormous quantities to obtain the silver and gold contained, which are relatively high in proportion; the pig lead or "base bullion" produced being sent eastward by railway to the refineries at Omaha, Chicago, St. Louis, Pittsburg, and even New York. The information given in the volume concerning this important branch of industry is so full that it will be a welcome one to the library of every metallurgist.

Another important and almost specially American mineral industry is that of petroleum, the production being restricted to the States of Pennsylvania, New York, California, West Virginia, Ohio, and Kentucky, the last four being, however, insignificant as compared with the first three. Here again there is a considerable disparity, the States of Pennsylvania and New York yielding 6r,200 barrels daily, while in California the annual total is only 70,000 barrels. The barrel contains 42 gallons U.S. measure, which is the same as the old English wine gallon of 231 cubic inches. The consuming power of the world seems in this article to have been passed by the supply, the average price of $4 \mathrm{Is} .2 d$. per barrel in 1864 having fallen to $3 s$. $4 d$. in 1883 . Notwithstanding this great fall in price the total produce of the year is valued at $£ 4,740,000$, or about one-half more than that of the copper.

The minor metallic and other minerals are of Jess importance, but their statistics are set forth in considerable detail in other parts of the volume, which we hope to see 
reprinted, if not annually, at least at short intervals of years, as furnishing one of the most valuable contributions to economic geology.

H. B.

\section{THE LATE DR. ENGELMANN}

SO many years have elapsed since Dr. Engel$S$ mann, whose death was recently announced in your columns, wrote his academic dissertation "De Antholysi Prodromus, 1832," that it is no matter for surprise if many among the younger generation of botanists have forgotten this little treatise, or have failed to associate its author with the historian of American conifers and other selected orders. This is the less surprising as, although in Dr. Engelmann's systematic memoirs there are frequent traces of his early morphological studies and of the interest he felt in them, he, so far as I know, wrote no treatise specially devoted to teratology other than the one already mentioned. A few words on this little book may therefore not be unacceptable to those who honour Engelmann's memory. It would be an interesting and not an unprofitable task to trace out the connection between teratology and the modern views of evolution, which is mucb closer than is generally imagined, albeit the ideas of natural selection and survival of the fittest find no place in the older teratological literature. For such a task I have neither the requisite ability nor the necessary leisure. My object in alluding to the matter is to call to mind the light in which Engelmann consitered the subject, influenced as he was by the writings of his great fellow-countryman Goethe, whose views, originally published in 1790 , were by no means universally accepted, even in 1832 . Schimper and Alexander Braun were among those who appreciated the value of Goethe's theory, and those two learned men and acute morphologists were Engelmann's teachers, and as we learn from himself, exerted great sway over him.

It is curious to contrast the modest pamphlet "De Antholysi Prodromus," written in Latin, which I at least do not find very easy to construe, with the more elaborate "Élémens de Tératologie Végétale" of Moquin-Tandon, published nearly ten years later (184I). Moquin's work is written in a style which even a foreigner can read with pleasure. Its method, too, is clear and symmetrical, but when we compare the two works from a philosophical point of view, and consider that the one was a mere college essay, while the other was the work of a professed botanist, we must admit that Engelmann's treatise, so far as it goes, affords evidence of deeper insight into the nature and causes of the deviations from the ordinary conformation of plants than does that of Moquin. A fe illustrations will suffice to make this clear. Speaking of pro. gressive development, or as he calls it " $e$ "volutionis progressus," Engelinann says that while it is only obscurely indicated in celestial bodies, and with difficulty studied in animals, "clarissine apparet in plantis." Plant-history is for Engelmann the narrative of the progress of evolution-" evolutio progrectiens"-and variations from the ordinary course are to be accounted for, "ex nimio motu, et ex nimio impeditione," or, as we should now say, from excess or from arrest of development.

The main end of a plant is to produce seed, and the morphology of the plant appears to have been considered by Engelmann as the result of a compromise between this tendency (nisus) and the progresive development of each individual part. The morpho'ogical unit for him, as for Goethe, from whom he derived the notion, was the leaf.-." unitas autem in foliis posita est"-and the variations from the leaf-type were, as we have seen, attributed to arrest of development, to reversion (regressus), or to progression. But these changes were looked upon then chiefly in relation to the greater or less development and specialisation of individual parts with little or no reference to their possible genealogical significance as elements in a general pedigree of plants, or at any rate as suggestive of such elements. Hereditary influence, however, was not wholly overlooked; on the contrary, Engelmann speaks of it as "magni momenti," and goes on to show how woody plants frequently show, year after year, the same malformations, how perennial plants less frequently do so, and how such repetition is much less frequently observable in annuals and plants propagated wholly by seed. Only "antholyses cpiphytice hereditaria esse possunt" (\$69), says our author, by which he means that partial changes are not perpetuated by descent, but only those in which "omnes plurimive flores morbosi sunt." It is not necessary to stop to consider what amount of truth there is in this assertion, but it is interesting to see the use then made of the word "epiphyte." Engelmann influenced by his medical studies, spoke of "local," "epiphytical," "sporadic," "enchoric," and "enchronic" affections; enchoric changes being limited to certain localities, enchronic alterations occurring at definite times. These terms have not been generally adopted, while the signification now attached to the word "epiphyte" is widely different from that which Engelmann intended. He, at least, had not the right of priority in this matter, for Bischoff, in his "Botanische Terminologie" (1830), speaks of epiphytes as external parasites (citing as examples Cuscuta and Viscum), in contradistinction to entophytes. It would seem from this that in matters of terminology custom overrides priority. But this by the way. Our present concern is with the fact that certain changes, or certain degrees of change, are more likely to be perpetuated than others. Similarly we find Engelmann calling attention to certain "critical" regions of the plant,-spots, that is, more subject than others to teratological change, - the apex of the stem in definite inflorescences for instance $(\$ 67)$, a point subsequently dwelt on by Darwin at so.ne length, though he does not seem to have been aware of what Engelmann had previously written on the subject.

Lastly, reference may be made to the assertion made by Engelmann that plants of a high state of relative structural perfection "structurat magis evolutâ et typo magis composito," are specially liable to retrograde metamorpbis. This is a statement that from the nature of things seems so reasonable that it is generally accepted without question. Nevertheless, it is one which requires qualification and further investigation. To take one case which occurs at the moment. Let any observer call to mind the number of instances in which he has seen the carpels the subjects of retroyrade metamorphosis, and he will probably find that such changes are far more common in cases where the carpels are free and superior, than in those in which they are in union one with another and with the thalamus, as in the so-called inferior ovaries, which are considered to represent a higher type of structure than do the free carpels.

But the object of this note is not to discuss any particular view that Engelmann may have held, but merely to call attention to his claims as a morphologist, claims which are overlooked by reason of his greater-numerically greater--claims as a systematist.

\section{MAXWEll T. MASTers}

\section{SIWALIK CARNIVORA ${ }^{1}$}

$\mathrm{BY}$ the publication of the present memoir on the Siwalik and Narbada Carnivora, Mr. Lydekker completes the second volume of the series of the "Palæontologia Indica " devoted to the Indian Tertiary and Post-Tertiary

I "Palæ untol gia Indica," Series x. Indian Tertiary and Post-Tertiary Vertebrata, Vul. ii. Part 6. Siwalik and Narbada Carnivora. By R. Lydekker, B.A., F.G.S., F.Z.S. Fublished by order of His Excellency the Governor-General of India in Council. (Calcutta, 1884.) 